\title{
Antenatally diagnosed kidney tumor: Answers
}

\author{
Wiebke Solass $^{1} \cdot$ Hyunkyu Shin ${ }^{1} \cdot$ Cristian Urla $^{2} \cdot$ Andreas Schmidt $^{2}$ (D) \\ Received: 4 October 2020 / Accepted: 4 November 2020 / Published online: 9 December 2020 \\ (C) The Author(s) 2020
}

Keywords Renal tumor $\cdot$ Prenatal diagnosis $\cdot$ Pediatric neoplasm $\cdot$ Nephrectomy $\cdot$ Congenital mesoblastic nephroma

\section{Answers}

The tumor developed during pregnancy in the upper pole of the left kidney and displayed spindle cell components with no atypia and islands of metaplastic cartilage, which is typical for a congenital mesoblastic nephroma (CMN), classic variant. Wilms tumor (WT)/nephroblastoma is the most frequent kidney tumor in childhood, and this diagnosis has to be considered [1]. Additional immunohistochemical staining is helpful to distinguish CMN from WT with heterologous differentiation $[1,2]$.

\section{Discussion}

Congenital mesoblastic nephroma represents $3 \%$ of all pediatric kidney tumors [3]. It is the most common kidney neoplasm diagnosed in the first 3 months of life, and it is frequently detected antenatally, as described in our case [4]. The malignant potential of the tumor is low.

\section{Histopathology}

The histological classification of CMN includes three subtypes: classic, cellular, and mixed type [5]. Classic CMN is composed of braiding bundles of spindle cells and frequent

This refers to the article that can be found at https://doi.org/10.1007/ s00467-020-04848-1.

Andreas Schmidt

andreas.schmidt@med.uni-tuebingen.de

1 Institute of Pathology and Neuropathology, University Hospital Tuebingen, Eberhard-Karls University Tuebingen,

Liebermeisterstraße 8, Tuebingen 72076, Germany

2 Department of Pediatric Surgery and Pediatric Urology, University Children's Hospital Tuebingen, Eberhard-Karls University Tuebingen, Hoppe-Seyler-Str. 3, 72076 Tuebingen, Germany metaplastic cartilage with no capsular boundaries. The tumor often infiltrates the surrounding perirenal fat tissue and parenchyma [6]. Cellular CMN also presents bundles of spindle cells but has a stronger hemangiopericytic pattern and a higher mitotic activity than the classic type. In contrast, the cellular type less frequently infiltrates the perirenal fat and/or kidney parenchyma. Mixed CMN shows, as the name indicates, a mixture of both abovementioned types.

\section{Molecular aspects}

There are recurrent genetic aberrations described in CMN, including somatic trisomy 11 and, occurring in the cellular and mixed type, the translocation $\mathrm{t}(12 ; 15)(\mathrm{p} 13 ; \mathrm{q} 25)$, which results in fusion of ETV6 and NTRK3 [7, 8]. Associations with genetic syndromes are only described in rare cases $[8,9]$.

\section{Therapy}

Complete nephrectomy is curative for most patients with stage $\mathrm{I} /$ II disease. The removal of perirenal fat during surgery is important, as CMN tumors often show infiltrative growth into the perirenal fat. However, in case of a high risk of operative or anesthetic complications, preoperative chemotherapy may be considered. Stage III tumors of the classic and mixed histologic subtype are also indicated for nephrectomy alone. Stage III tumors of the cellular type treated only surgically have a higher rate of relapse than the other histologic subtypes requiring chemotherapy or radiotherapy in some cases. However, due to limited data, there are no specific recommendations for adjuvant chemotherapy [8]. The known side effects of radiotherapy particularly in these very young patients limit this treatment modality to selected cases with aggressive tumors not responding to chemotherapy [8].

For the targeted therapy of tumors with the ETV6-NTRK3 fusion, tropomyosin receptor kinase inhibitors have been developed. One drug was recently approved for children with $\mathrm{CMN}$ 
and proven ETV6-NTRK3 fusion who lack other treatment options [10]. However, conclusive data regarding the outcome of patients after application of the drug are not available.

Taking into account these aspects, it may be concluded that the decision for the adequate treatment of patients with $\mathrm{CMN}$ may sometimes be challenging. Therefore, the importance of an adequate diagnostic and therapeutic plan established by an interdisciplinary reference board which should include a pediatric oncologist, pediatric radiologist, pediatric surgeon, and pathologist cannot be overemphasized.

\section{Conclusion}

In summary, CMN is a rare and in most cases a nonaggressive tumor. It is classified into three histological subtypes. Frequently, the tumor is diagnosed antenatally. Most tumors are treated with surgery only. Pre- and postoperative chemotherapy is only administered in particular cases. Nephroblastoma is a possible differential diagnosis.

Funding Open Access funding enabled and organized by Projekt DEAL.

\section{Compliance with ethical standards}

Conflict of interest The authors declare that they have no conflicts of interest.

Consent for publication Written informed consent for publication of the clinical details and clinical images was obtained from the parents of the patient. A copy of the consent form is available for review by the Editor of this journal.

Open Access This article is licensed under a Creative Commons Attribution 4.0 International License, which permits use, sharing, adaptation, distribution and reproduction in any medium or format, as long as you give appropriate credit to the original author(s) and the source, provide a link to the Creative Commons licence, and indicate if changes were made. The images or other third party material in this article are included in the article's Creative Commons licence, unless indicated otherwise in a credit line to the material. If material is not included in the article's Creative Commons licence and your intended use is not permitted by statutory regulation or exceeds the permitted use, you will need to obtain permission directly from the copyright holder. To view a copy of this licence, visit http://creativecommons.org/licenses/by/4.0/.

\section{References}

1. van den Heuvel-Eibrink MM, Grundy P, Graf N, Pritchard-Jones $\mathrm{K}$, Bergeron C, Patte C, van Tinteren H, Rey A, Langford C, Anderson JR, de Kraker J (2008) Characteristics and survival of 750 children diagnosed with a renal tumor in the first seven months of life: a collaborative study by the SIOP/GPOH/SFOP, NWTSG, and UKCCSG Wilms tumor study groups. Pediatr Blood Cancer 50:1130-1134. https://doi.org/10.1002/pbc.21389

2. Ooms A, Vujanic GM, D'Hooghe E, Collini P, L'HermineCoulomb A, Vokuhl C, Graf N, Heuvel-Eibrink M, de Krijger RR (2020) Renal tumors of childhood-a histopathologic patternbased diagnostic approach. Cancers (Basel) 12:729. https://doi. org/10.3390/cancers12030729

3. Pettinato G, Manivel JC, Wick MR, Dehner LP (1989) Classical and cellular (atypical) congenital mesoblastic nephroma: a clinicopathologic, ultrastructural, immunohistochemical, and flow cytometric study. Hum Pathol 20:682-690. https://doi.org/10.1016/ 0046-8177(89)90156-1

4. Furtwaengler R, Reinhard H, Leuschner I, Schenk JP, Goebel U, Claviez A, Kulozik A, Zoubek A, von Schweinitz D, Graf N, Gesellschaft fur Padiatrische Onkologie und Hamatologie Nephroblastoma Study Group (2006) Mesoblastic nephroma-a report from the Gesellschaft fur Padiatrische Onkologie und Hamatologie (GPOH). Cancer 106:2275-2283. https://doi.org/10. $1002 /$ cncr. 21836

5. Sandstedt B, Delemarre JF, Krul EJ, Tournade MF (1985) Mesoblastic nephromas: a study of 29 tumours from the SIOP nephroblastoma file. Histopathology 9:741-750. https://doi.org/ 10.1111/j.1365-2559.1985.tb02860.x

6. Argani P, Ladanyi M (2003) Recent advances in pediatric renal neoplasia. Adv Anat Pathol 10:243-260. https://doi.org/10.1097/ 00125480-200309000-00001

7. Knezevich SR, Garnett MJ, Pysher TJ, Beckwith JB, Grundy PE, Sorensen PH (1998) ETV6-NTRK3 gene fusions and trisomy 11 establish a histogenetic link between mesoblastic nephroma and congenital fibrosarcoma. Cancer Res 58:5046-5048

8. Gooskens SL, Houwing ME, Vujanic GM, Dome JS, Diertens T, Coulomb-l'Hermine A, Godzinski J, Pritchard-Jones K, Graf N, van den Heuvel-Eibrink MM (2017) Congenital mesoblastic nephroma 50 years after its recognition: a narrative review. Pediatr Blood Cancer 64(7). https://doi.org/10.1002/pbc.26437

9. Sutherland RW, Wiener JS, Hicks MJ, Hawkins EP, Chintagumpala M (1997) Congenital mesoblastic nephroma in a child with the Beckwith-Wiedemann syndrome. J Urol 158:15321533

10. Federman N, McDermott R (2019) Larotrectinib, a highly selective tropomyosin receptor kinase (TRK) inhibitor for the treatment of TRK fusion cancer. Expert Rev Clin Pharmacol 12:931-939. https://doi.org/10.1080/17512433.2019.1661775

Publisher's note Springer Nature remains neutral with regard to jurisdictional claims in published maps and institutional affiliations. 